\title{
Comparison of virus isolation using the Vero E6 cell line with real-time RT-PCR assay for the detection of human metapneumovirus
}

\author{
Yoko Matsuzaki 1,8, Katsumi Mizuta*2, Emi Takashita³, Michiko Okamoto4,9, Tsutomu Itagaki5, Fumio Katsushima6, \\ Yuriko Katsushima6, Yukio Nagai ${ }^{7}$ and Hidekazu Nishimura ${ }^{4}$
}

\begin{abstract}
Background: The use of cell culture for the diagnosis of human metapneumovirus (hMPV) infection is uncommon at present and molecular method such as reverse-transcription PCR (RT-PCR) has been widely and most commonly used as the preferred test. We aimed to compare the results of virus isolation using Vero E6 cells with real-time RT-PCR for the detection of hMPV, since such a comparison data is not available.

Methods: Between December 2007 and July 2008, we obtained 224 nasopharyngeal swab specimens from patients with acute respiratory infection and tested by the two methods.

Results: Forty-three (19.2\%) were found positive by cell culture and 62 (27.7\%) by real-time RT-PCR. Cell cultures were positive for 42 of 62 specimens found positive by real-time RT-PCR (67.7\% sensitivity) and for 1 of 162 specimens found negative by real-time RT-PCR ( $99.4 \%$ specificity), respectively. The sensitivity of the cell culture was $76.2-87.5 \%$ (mean 81.8\%) when specimens were collected within 3 days after the onset of symptoms, and the sensitivity decreased to $50 \%$ or less thereafter. Among specimens collected within 3 days after symptom onset, all of the real-time RT-PCR positive specimens having a viral load of more than $1.25 \times 10^{5} \mathrm{copies} / \mathrm{ml}$ were found positive by cell culture.

Conclusions: Cell culture using Vero E6 cell line has $81.8 \%$ sensitivity compared with the real-time RT-PCR method, when specimens are collected within 3 days after the onset of symptoms. Thus, this method is a useful method for epidemiological and virological research even in facilities with minimal laboratory resources.
\end{abstract}

\section{Background}

Human metapneumovirus (hMPV) was first described in 2001 following its isolation from nasopharyngeal specimens from infants and children with acute respiratory infection (ARI) in The Netherlands and it has been categorized as a member of the genus Metapneumovirus of the subfamily Pneumovirinae of the family Paramyxoviridae [1-3]. It has been recognized as an important agent responsible for respiratory tract disease worldwide, especially in the pediatric and elderly populations [2-5], with serological studies having revealed that hMPV seropositivity is almost universal by the age of 5 years $[3,6]$.

* Correspondence: mizutak@eiken.yamagata.yamagata.jp

2 Department of Microbiology, Yamagata Prefectural Institute of Public Health, Tokamachi 1-6-6, Yamagata, 990-0031, Japan

Full list of author information is available at the end of the article
For laboratory diagnosis, the most definitive test is virus isolation by cell culture [3]. Although hMPV isolation has commonly been performed using the LLC-MK2 or Vero cell lines, the growth of hMPV is slow and often requires several blind passages before any cytopathic effect (CPE) is apparent, particularly following primary isolation $[1,3-5,7,8]$. Thus, it is believed that virus isolation is difficult, being possible in only one-third to onehalf of cases in which nasopharyngeal samples are found to positive for hMPV by reverse-transcription PCR (RTPCR) $[2,3,5,9]$. The use of cell culture for the diagnosis of hMPV infection is uncommon at present and RT-PCR has been widely and most commonly used as the preferred test due to its sensitivity [2,3]. In our previous study, we demonstrated that the infection efficiency of hMPV in Vero E6 cells was more than 5 to 20 times better than that in LLC-MK2 cells and, in fact, we succeeded in 
isolating nearly 100 strains between 2004 and 2006 using this cell line $[6,10,11]$. However, there is no data on the effectiveness of virus isolation in comparison with realtime RT-PCR for hMPV detection from clinical specimens, since virus isolation is not common. In this paper, we show the results of virus isolation from 224 clinical specimens using Vero E6 cells and the real-time RT-PCR method.

\section{Methods}

A total of 224 nasopharyngeal swab specimens were collected from patients who had been clinically diagnosed with ARI with fever and/or cough and/or rhinorrhea at 3 pediatric clinics in Yamagata and Sendai between December 2007 and July 2008, as described previously for the evaluation of a newly developed rapid antigen detection kit using immunochromatography compared with real-time RT-PCR [12]. The specimens were collected and used for the previous and present studies, after getting the informed consent from the patients or their guardians. These studies were approved by the Institutional Review Board of Sendai Medical Center, National Hospital Organization Japan, on Feb. 29, 2008 (Reference No CHI-19-33). Of these specimens, 166 were from children aged under 5 years, 43 were from children aged between 5 and 9 years, 7 were from children aged between 10 and 15 years and 8 were from patients $>15$ years. Each specimen was placed immediately in a tube containing $3 \mathrm{ml}$ of transport medium [11,12] and transported at $4^{\circ} \mathrm{C}$ to the Department of Microbiology, Yamagata Prefectural Institute of Public Health for virus isolation and real-time RT-PCR. Prior to specimen inoculation for virus isolation, $200 \mu \mathrm{l}$ of the specimen was transferred to a $1.5 \mathrm{ml}$ microtube and stocked at $-80^{\circ} \mathrm{C}$ until application to real-time RT-PCR assay. Virus isolation was carried out by the 96-well modified microplate method including Vero E6 and other five cell lines [10,11]. We observed the plates two or three times per week for CPEs for 4 weeks without passage or medium change [10]. When a hMPV-like CPE was observed, second passage, identification and genotyping was carried out as described previously [10]. The method and results of real-time RT-PCR assay with a TaqMan probe using an ABI Prism 7500 Fast real-time PCR system (Applied Biosystems) were described previously [12]. Primers and a probe targeting the hMPV N gene were designed based on the reports of Maertzdorf et al. [13] and Bonroy et al. [14]. Statistical analysis was performed by Fisher's exact probability test.

\section{Results}

As a result, 62 specimens (27.7\%) were found positive by real-time RT-PCR, and $43(19.2 \%)$ by cell culture as shown in Table 1 . One of the 43 cell culture-positive spec- imen was found negative by real-time RT-PCR. This may be a false-positive result obtained by cell culture or rather a false-negative by real-time RT-PCR. On the other hand, 20 of the 62 real-time RT-PCR-positive specimens were found negative by cell culture. Therefore, the sensitivity and specificity of cell culture for the detection of hMPV were $67.7 \%(42 / 62)$ and $99.4 \%$ (161/162), respectively, compared with real-time RT-PCR. The agreement between the results of cell culture and real-time RT-PCR was $90.6 \%(203 / 224)$.

Viral loads of the 62 specimens tested positive by realtime RT-PCR were distributed between $1.99 \times 10^{2}$ and $3.85 \times 10^{6}$. The results of the real-time RT-PCR are shown in Figure 1. All of the real-time RT-PCR-positive specimens having more than $1.25 \times 10^{5} \mathrm{hMPV}$ copies/ml were also found positive by cell culture, though two specimens with $8.79 \times 10^{5}$ and $1.36 \times 10^{6}$ copies $/ \mathrm{ml}$ that were collected on Day 4 and 5 after the onset of symptoms, respectively, were negative. The sensitivity of virus isolation for specimens obtained at 1-3 days after the onset of symptoms was $76.2-87.5 \%$ (mean $81.8 \%$ ), whereas it was less than $25-50 \%$ (mean $33.3 \%$ ) for $4-7$ days (Table 1). The sensitivity of virus isolation for specimens obtained within 3 days after the onset of symptoms was statistically higher than that for specimens obtained more than 3 days after the onset of symptoms $(P=.0006)$.

\section{Discussion}

Since the date of specimen collection is important, we should distinguish the data obtained at 1-3 days after the onset of symptoms from thereafter, when we compare virus isolation with real-time RT-PCR method. The sensitivity of virus isolation for specimens during this period was $76.2-87.5 \%$ (mean $81.8 \%$ ). However, the sensitivity decreased for specimens collected on Day 4 and thereafter. This indicates that the excretion of hMPV infectious particles may decrease after 4 days from the onset of symptoms, which is in agreement with previous data for respiratory syncytial virus that indicates the predictive value of virus isolation is highest when respiratory specimens are collected 1-3 days after the onset of symptoms [15]. Therefore, specimens for cell culture should be collected within three days after the onset of symptoms. The merit of real-time RT-PCR over cell culture rests in that it is able to detect hMPV genome with or without infectivity during this period. Since the two detection methods described here differ significantly in cost, turn-aroundtime and technical difficulty, we should use each method depending on the purpose.

\section{Conclusions}

Cell culture using Vero E6 cell line has approximately 80\% sensitivity compared with the real-time RT-PCR method when specimens are collected within 3 days after the 
Table 1: Comparison of virus isolation with real-time RT-PCR in hMPV detection

\begin{tabular}{|c|c|c|c|c|c|c|c|}
\hline \multirow{2}{*}{$\begin{array}{l}\text { Days of specimen collection } \\
\text { after onset of illness }\end{array}$} & \multirow{2}{*}{$\begin{array}{c}\text { No. of } \\
\text { specimens }\end{array}$} & \multicolumn{4}{|c|}{ No. of specimens with the following resultsa: } & \multirow{2}{*}{$\begin{array}{c}\text { Sensitivity } \\
\text { (\%) }\end{array}$} & \multirow{2}{*}{$\begin{array}{c}\text { Specificity } \\
(\%)\end{array}$} \\
\hline & & $\mathrm{P}+, \mathrm{C}_{+}$ & $\mathrm{P}+, \mathrm{C}-$ & $\mathrm{P}_{-}, \mathrm{C}_{+}$ & P-,C- & & \\
\hline 1 & 48 & 13 & 2 & 0 & 33 & 86.7 & 100 \\
\hline 2 & 77 & 16 & 5 & 0 & 56 & 76.2 & 100 \\
\hline 3 & 38 & 7 & 1 & 0 & 30 & 87.5 & 100 \\
\hline 4 & 25 & 3 & 3 & 1 & 18 & 50 & 94.7 \\
\hline$>4$ & 36 & 3 & 9 & 0 & 24 & 25 & 100 \\
\hline $1-7$ & 224 & 42 & 20 & 1 & 161 & 67.7 & 99.4 \\
\hline
\end{tabular}

aAbbreviations; P, real-time RT-PCR; C, cell culture

onset of symptoms. Along with its consistency in not producing false-positive results, cell culture using the Vero E6 cell line to be regarded as a useful method for epidemiological and virological research, through not for rapidly clinical diagnosis. Furthermore, this cell culture method might be applicable in facilities with minimal laboratory resources without expensive real-time RT-PCR system.

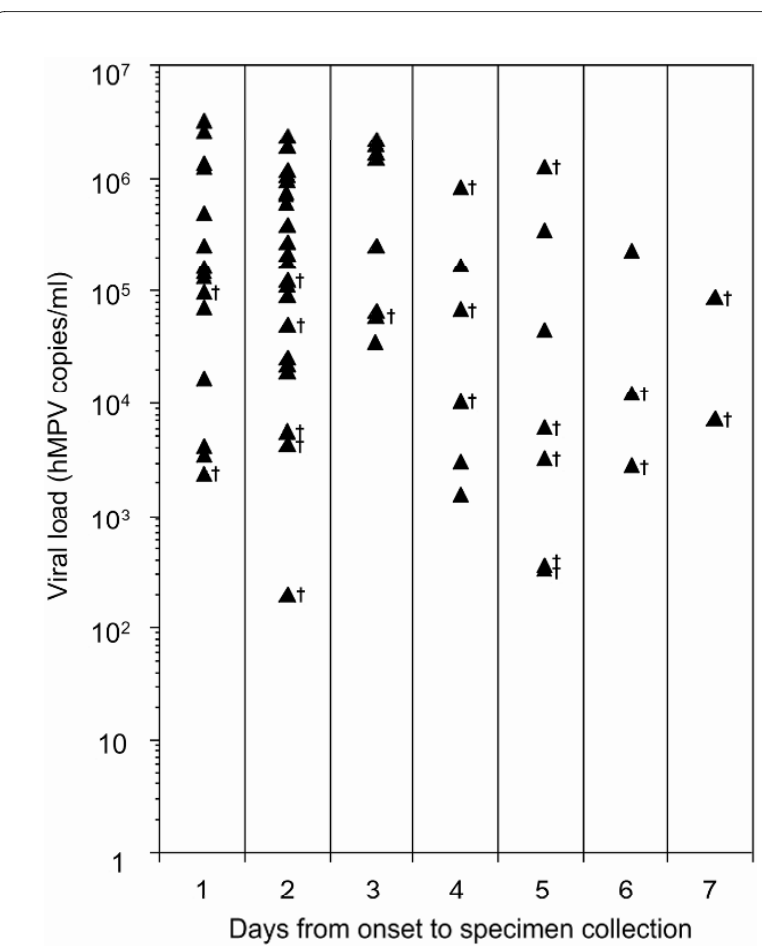

Figure 1 Viral loads of real-time RT-PCR-positive specimens and the number of days from onset of fever to specimen collection. Solid triangles indicate the 62 specimens that tested positive for hMPV by real-time RT-PCR assay. Specimens testing negative by cell culture are marked with daggers.

\section{Abbreviations}

HMPV: human metapneumovirus; ARI: acute respiratory infection; CPE: cytopathic effect; RT-PCR: reverse-transcription PCR

\section{Competing interests}

The authors declare that they have no competing interests.

\section{Authors' contributions}

All authors have made substantial contributions to design and acquisition of data. YM, KM and $\mathrm{HN}$ also contributed for analysis of data, drafting and revising the manuscript. All authors read and approved the final manuscript.

\section{Acknowledgements}

This work was supported in part by Ohkura Pharmaceutical Co., Ltd. We also thank the medical staff and people of Yamagata Prefecture and of Miyagi Prefecture for their collaboration in specimen collection for the surveillance of viral infectious diseases.

\section{Author Details}

'Course of Clinical Nursing, Yamagata University Faculty of Medicine, lida-nishi, 2-2-2, Yamagata, 990-9585, Japan, ²Department of Microbiology, Yamagata Prefectural Institute of Public Health, Tokamachi 1-6-6, Yamagata, 990-0031, Japan, ${ }^{3}$ Influenza Virus Research Center, National Institute of Infectious Diseases, Gakuen 4-7-1, Musashimurayama, Tokyo, 208-0011, Japan, 4Virus Research Center, Clinical Research Division, Sendai Medical Center, Miyaginoku Miyagino 2-8-8, Sendai, 983-8520, Japan, ${ }^{5}$ Yamanobe Pediatric Clinic Yamanobe 2908-14, Yamagata, 990-0301, Japan, 6Katsushima Pediatric Clinic Minamidate 4-4-12, Yamagata, 990-2461, Japan, 7 Nagai Children's Clinic, Miyagino-ku Miyagino 1-25-10, Sendai, 983-0045, Japan, ${ }^{8}$ Department of Infectious Diseases, Yamagata University Faculty of Medicine, lida-nishi 2-2-2, Yamagata, 990-9585, Japan and 9 Department of Virology Tohoku University Graduate School of Medicine, Seiryo-machi 2-1, Aoba-ku, Sendai, 980-8575, Japan

Received: 4 December 2009 Accepted: 14 June 2010 Published: 14 June 2010

\section{References}

1. van den Hoogen BG, de Jong JC, Groen J, Kuiken T, de Groot R, Fouchier RAM, Osterhaus ADME: A newly discovered human pneumovirus isolated from young children with respiratory tract disease. Nat. Med 2001, 7:719-724.

2. Kahn JS: Epidemiology of human metapneumovirus. Clin. Microbiol. Rev 2006, 19:546-557.

3. Collins PL, Crowe JE Jr: Respiratory syncytial virus and metapneumovirus. In Fields Virology Volume 2. 5th edition. Edited by: Knipe DM, Howley PM. Philadel phia: Lippincott Williams \& Wilkins; 2007:1601-1646.

4. Falsey AR, Erdman D, Anderson LJ, Walsh EE: Human metapneumovirus infections in young and elderly adults. J. Infect. Dis 2003, 187:785-790. 
5. Williams JV, Harris PA, Tollefson SJ, Halburnt-Rush LL, Pingsterhaus JM, Edwards KM, Wright PF, Crowe JE Jr: Human metapneumovirus and lower respiratory tract disease in otherwise healthy infants and children. N. Engl. J. Med 2004, 350:443-450,

6. Matsuzaki Y, Itagaki T, Abiko C, Aoki Y, Suto A, Mizuta K: Clinical impact of human metapneumovirus genotypes and genotype-specific seroprevalence in Yamagata, Japan. J. Med. Virol 2008, 80:1084-1089.

7. Boivin G, Abed Y, Pelletier G, Ruel L, Moisan D, Côté S, Peret TCT, Erdman $\mathrm{DD}$, Anderson $\mathrm{LJ}$ : Virological features and clinical manifestations associated with human metapneumovirus: a new paramyxovirus responsible for acute respiratory-tract infections in all age groups. $J$. Infect. Dis 2002, 186:1330-1334.

8. Peret TCT, Boivin G, Li Y, Couillard M, Humphrey C, Osterhaus ADME, Erdman DD, Anderson LJ: Characterization of human metapeumoviruses isolated from patients in North America. J. Infect. Dis 2002, 185:1660-1663.

9. Ebihara T, Endo R, Ma X, Ishiguro N, Kikuta H: Detection of human metapneumovirus antigens in nasopharyngeal secretions by an immunofluorescent-antibody test. J. Clin. Microbiol 2005, 43:1138-1141.

10. Abiko C, Mizuta K, Itagaki T, Katsushima N, Ito S, Matsuzaki Y, Okamoto M, Nishimura H, Aoki Y, Murata T, Hoshina H, Hongo S, Ootani K: Outbreak of human metapneumovirus detected by use of the Vero E6 cell line in isolates collected in Yamagata, Japan, in 2004 and 2005. J. Clin. Microbiol 2007, 45:1912-1919.

11. Mizuta K, Abiko C, Aoki Y, Suto A, Hoshina H, Itagaki T, Katsushima N, Matsuzaki Y, Hongo S, Noda M, Kimura H, Ootani K: Analysis of monthly isolation of respiratory viruses from children by cell culture using a microplate method: a two-year study from 2004 to 2005 in Yamagata, Japan. Jpn. J. Infect. Dis 2008, 61:196-201.

12. Matsuzaki Y, Takashita E, Okamoto M, Mizuta K, Itagaki T, Katsushima F, Katsushima Y, Nagai Y, Nishimura H: Evaluation of a new rapid antigen test using immunochromatography for detection of human metapneumovirus in comparison with real-time PCR assay. J. Clin. Microbiol 2009, 47:2981-2984.

13. Maertzdorf J, Wang CK, Brown JB, Quinto JD, Chu M, de Graaf M, van den Hoogen BG, Spaete R, Osterhaus ADME, Fouchier RAM: Real-time reverse transcriptase PCR assay for detection of human metapneumoviruses from all known genetic lineages. J. Clin. Microbiol 2004, 42:981-986.

14. Bonroy C, Vankeerberghen A, Boel A, De Beenhouwer H: Use of a multiplex real-time PCR to study the incidence of human metapneumovirus and human respiratory syncytial virus infections during two winter seasons in a Belgian paediatric hospital. Clin. Microbiol. Infect 2007, 13:504-509.

15. Wiedbrauk DL, Johnston SLG: Respiratory Syncytial Virus. In Manual of clinical virology Volume 1993. New York: Raven Press :184-195.

\section{Pre-publication history}

The pre-publication history for this paper can be accessed here: http://www.biomedcentral.com/1471-2334/10/170/prepub

\section{Submit your next manuscript to BioMed Central} and take full advantage of:

- Convenient online submission

- Thorough peer review

- No space constraints or color figure charges

- Immediate publication on acceptance

- Inclusion in PubMed, CAS, Scopus and Google Scholar

- Research which is freely available for redistribution 